\title{
HUBUNGAN JUMLAH LEUKOSIT DENGAN MOTILITAS SPERMATOZOA PADA ANALISIS SEMEN PRIA DI SAMMARIE FAMILY HEALTHCARE 2019
}

\author{
Wanodia Ayutama $^{1}$, Tuty Rizkianti², Cut Fauziah ${ }^{3}$ \\ ${ }^{1}$ Program Studi Kedokteran Program Sarjana, FK UPN Veteran Jakarta \\ Email: wanodiaayutama@gmail.com \\ ${ }^{2}$ Departemen Patologi Klinik, FK UPN Veteran Jakarta \\ Email: rizkianti75@gmail.com \\ ${ }^{3}$ Departemen Biologi, FK UPN Veteran Jakarta \\ Email:coet.biomed@yahoo.com
}

\begin{abstract}
ABSTRAK
Infertilitas merupakan salah satu masalah kesehatan reproduksi pria yang sering dijumpai. Infertilitas pada pria adalah ketidakmampuan seorang pria untuk menyebabkan kehamilan pada seorang wanita fertil setelah satu tahun hubungan seksual tanpa alat kontrasepsi. Pria dengan kualitas sperma yang kurang baik lebih rentan mengalami infertilitas. Salah satu penyebab infertilitas pada pria adalah gangguan pada motilitas spermatozoa. Motilitas yang kurang sempurna akan menyebabkan penurunan kualitas spermatozoa dan penurunan probabilitas terjadinya pembuahan. Salah satu penyebab penurunan motilitas adalah inflamasi pada saluran reproduksi pria. Inflamasi yang terjadi akan meningkatkan rekruitmen leukosit pada saluran reproduksi pria dan meningkatkan produksi reactive oxygen species (ROS) yang bersifat toksik bagi spermatozoa sehingga dapat mengganggu proses pembentukan dan pematangan spermatozoa. Tujuan penelitian ini adalah untuk mengetahui hubungan antara jumlah leukosit dengan motilitas spermatozoa. Jumlah leukosit dan persentase motilitas spermatozoa didapatkan dari data sekunder, yaitu data hasil analisis semen. Desain penelitian yang digunakan adalah potong lintang (cross-sectional). Jumlah sampel dalam penelitian ini sebanyak 81 pasien yang memenuhi kriteria inklusi. Hasil dari penelitian menunjukkan terdapat hubungan terbalik (korelasi negatif) yang bermakna dengan kekuatan korelasi sangat lemah $(p=0.007, r=-0.328)$ antara jumlah leukosit dengan motilitas spermatozoa, yang berarti jika jumlah leukosit semen semakin meningkat, maka persentase motilitas spermatozoa akan semakin rendah.
\end{abstract}

Kata Kunci: inflamasi; jumlah leukosit; motilitas spermatozoa

\begin{abstract}
Infertility is one of the most common male reproductive health problems. Male infertility is the inability of a male to result pregnancy in a fertile female in one year of non-contracepting sexual intercourse. Male with poor sperm quality are more susceptible to infertility. One of the cause of infertility in men is disruption of spermatozoa motility. Imperfect motility will reduce the quality of spermatozoa and the probability of conception. One cause of decreased motility is inflammation of the male reproductive tract. Inflammation that occurs will increase the recruitment of leukocytes in the reproductive tract and increase the production of reactive oxygen species (ROS) so it can interfere the process of sperm formation and maturation. The purpose of this study was to determine the relationship between leukocyte counts and spermatozoa motility. The number of leukocytes and the percentage of spermatozoa motility were obtained from semen analysis as secondary data. The research design used was cross-sectional. The number of samples in this study were 66 respondents who met the inclusion criteria.The results of the study showed a significant inverse relationship (negative correlation) $(p=0.007, r=-0.328$ ) between the number of leukocytes and spermatozoa motility, which means if the number of semen leukocytes increases, the percentage of spermatozoa motility will decrease.
\end{abstract}

Keywords: inflammation; leukocyte counts; spermatozoa motility 


\section{PENDAHULUAN \\ Latar Belakang}

Semen merupakan hasil sekresi kelamin jantan secara normal yang diejakulasikan pada saat perkawinan. Semen terdiri dari dua bagian yaitu plasma seminalis dan spermatozoa atau sel kelamin jantan (Hardijanto, 2010). Spermatozoa adalah sel seks, sel kelamin, atau gamet pria yang membuahi sel telur wanita atau ovum pada saat reproduksi. Perkiraan kompetensi fungsional sperma dapat dievaluasi melalui analisis semen (Sheikh et al., 2008). Analisis semen merupakan salah satu pemeriksaan awal yang dilakukan pada kasus infertilitas. Tujuan analisis semen adalah untuk mengetahui kondisi sperma, hasilnya dapat menentukan apakah sperma tersebut fertil atau infertil (Tandara et al., 2013).

Pada pria, infertilitas merupakan salah satu masalah kesehatan reproduksi yang sering dijumpai. Salah satu penyebab infertilitas pada pria adalah gangguan pada sperma (36\%). Empat kategori utama cacat sperma mengarah ke diagnosis infertilitas pria adalah jumlah sperma yang sedikit (oligozoospermia), masalah pada motilitas sperma (asthenozoospermia), cacat morfologi sperma (teratozoospermia), dan tidak adanya sperma dalam semen (azoospermia), yang mungkin terjadi karena kurangnya produksi atau obstruksi (Parrot, 2014).

Motilitas sperma adalah salah satu faktor yang berperan penting dalam penentuan sperma normal (Singh dan Agarwal, 2011). Menurut WHO (2010) motilitas spermatozoa dibedakan menjadi Progressive motility (PR), Non-progressive motility (NP), Immotility (IM). Sperma dikatakan normal apabila total spermatozoa motil mencapai $40 \%$, dengan presentasi motilitas progresif $32 \%$. Beberapa faktor yang memengaruhi motilitas sperma adalah usia, berat badan, stres, konsumsi alkohol, pekerjaan, radiasi gelombang elektromagnetik, dan infeksi (Ansalsi, 2017). Inflamasi dan infeksi organ reproduksi laki-laki akan meningkatkan jumlah leukosit di cairan semen yang nantinya memengaruhi motilitas sperma (Al-Haija, 2011; Henkel, 2011; Vignera et al., 2012; Carrel, 2013).

Leukosit atau sel darah putih adalah sel darah yang tidak berwarna yang mampu bergerak secara ameboid (Dorland, 2002), dan merupakan unit aktif dari sistem pertahanan tubuh manusia (Widodo, 2009). Dalam semen, leukosit berperan dalam sistem kekebalan dan fagositik sperma abnormal. Ditemukannya leukosit yang meningkat hebat jumlahnya di dalam semen merupakan indikasi adanya inflamasi atau infeksi pada saluran reproduksi (Widodo, 2009). Peningkatan leukosit pada organ reproduksi ini dapat menyebabkan terjadinya leukositospermia, yaitu kondisi ditemukannya konsentrasi leukosit dalam ejakulat lebih dari nilai referensi, yaitu $<1 \times 10^{6} / \mathrm{mL}$ (WHO, 2010; Agustinus, 2019). Leukositospermia dapat ditemukan hingga 5-10\% populasi, dan dapat mencapai $20 \%$ pada pria yang mencari pengobatan fertilitas. Kejadian leukositospermia identik dengan kejadian PMS yang disebabkan oleh infeksi retrovirus, chlamidia, dan gonorrhea. Di sisi lain, peningkatan leukosit berlebihan dalam semen dapat meningkatan jumlah reactive oxygen species (ROS) yang jika dalam jumlah banyak dapat mengganggu proses spermatogenesis dan merusak spermatozoa normal, sehingga dapat memengaruhi fertilitas seorang pria. Reactive oxygen species (ROS), yaitu kelompok radikal bebas yang dalam konsentrasi rendah bermanfaat untuk hiperaktivasi sperma, sedangkan dalam konsentrasi tinggi memiliki pengaruh negatif pada fungsi sperma (Shi, 2009; Lackner et al., 2010; Piomboni, 2012; Pereira et al., 2017) Leukositospermia dapat menurunkan motilitas spermatozoa dan kapasitas fertilisasi in vitro yang mengakibatkan penurunan transpor dan ketahanan sperma pada saluran reproduksi wanita (Widodo, 2009) dan menjadi salah satu faktor dari infertilitas. 
Lackner pada penelitiannya menyatakan bahwa persentase sperma dengan morfologi normal dan motilitas progresif lebih banyak ditemukan pada sampel semen dengan kadar leukosit $<1 \times 10^{6} / \mathrm{mL}$ dibanding pada sampel semen dengan jumlah leukosit $>1 \times 10^{6} / \mathrm{mL}$ (Lackner et al., 2010) Sedangkan Ansalsi, tidak menemukan adanya korelasi antara jumlah leukosit dengan penurunan motilitas sperma (2017). Kontroversi tersebut dikerucutkan menjadi suatu permasalahan yang utama, yaitu definisi dari leukositospermia patologis dan hubungan antara jumlah lekosit dengan stress oksidatif seminal masih belum jelas (Sandoval et al., 2013). Meskipun World Health Organization (WHO) menyatakan leukositospermia patologis terjadi ketika jumlah leukosit $>1 \times 10^{6} / \mathrm{mL}$ semen, adanya variasi individu yang beragam mengakibatkan jumlah minimum leukosit yang dapat menyebabkan infertilitas bisa lebih tinggi atau lebih rendah.

Sampai saat ini belum ada data valid mengenai hubungan jumlah leukosit dengan kualitas spermatozoa. Beberapa penelitian menyebutkan ada penurunan kualitas, salah satunya motilitas spermatozoa pada semen dengan leukositospermia, sedangkan pada penelitian lain menyebutkan tidak ada korelasi yang signifikan antara jumlah leukosit dengan motilitas spermatozoa. Dengan demikian, masalah dari penelitian ini adalah bagaimanakah hubungan jumlah leukosit dengan motilitas spermatozoa?

\section{METODE PENELITIAN}

\section{Desain Penelitian}

Penelitian ini merupakan penelitian analitik observasional dengan tujuan untuk mengetahui hubungan antar variabel menggunakan pendekatan cross-sectional dengan mencatat hasil pemeriksaan laboraturium pasien. Survei cross sectional merupakan suatu studi observasional untuk menentukan hubungan antara variabel bebas (faktor risiko) dan variabel terikat (penyakit) dengan melakukan pengukuran sesaat (Sastroasmoro, 2014).

\section{Populasi dan Sampel}

Pada penelitian ini, populasi yang akan diteliti adalah seluruh pasien yang memeriksakan analisa semen di SamMarie Family Healthcare Jakarta periode bulan Januari - Agustus tahun 2019.

Sampel yang dipilih merupakan seluruh pasien yang memeriksakan analisis semen di SamMarie Family Healthcare yang memenuhi kriteria yaitu pasien yang memiliki hasil ananlisis semen lengkap, baik mikroskopis maupun makroskopis.

\section{Pengambilan Sampel}

Penelitian ini menggunakan pengambilan sampel non-probability sampling yaitu consecutive random sampling.

\section{Pengumpulan Data}

Sumber data merupakan data sekunder yaitu data pasien yang didapatkan dari hasil analisis semen pasien yang memeriksakan spermanya di SamMarie Family Healthcare pada bulan Januari - Agustus tahun 2019.

\section{Prosedur Penelitian}

Peneliti melakukan pengambilan sampel dengan cara membuka hasil analisis semen pasien lalu mencatat data yang diperlukan untuk penelitian. 


\section{HASIL DAN PEMBAHASAN}

\section{Karakteristik Responden}

Karakteristik sampel penelitian meliputi usia dan diagnosis. Tabel 1 adalah tabel distribusi karakteristik responden penelitian. Pada penelitian ini didapatkan 81 data pasien yang berusia 24-54 tahun. Didapatkan pasien yang memeriksakan kesuburannya paling banyak pada kelompok usia 30-39 tahun, yaitu sebanyak 46 orang (57\%) dan paling sedikit pada kelompok usia $>50$ tahun, yaitu hanya 2 orang $(2 \%)$. Diagnosis terbanyak dari pasien pada penelitian ini adalah oligoasthenoteratozoospermia (OAT) sebanyak 38 orang (47\%) dan paling sedikit oligozoospermia sebanyak 1 orang $(1 \%)$ dan oligoteratozoospermia sebanyak 1 orang $(1 \%)$.

Tabel 1. Distribusi Karakteristik Responden Penelitian

\begin{tabular}{llll}
\hline No. & \multicolumn{1}{c}{ Karakteristik } & $\boldsymbol{n}$ & \% \\
\hline $\mathbf{1}$ & Usia & & 24 \\
\hline & 20-29 Tahun & 19 & 57 \\
\hline 30-39 Tahun & 46 & 17 \\
\hline 40-49 Tahun & 14 & 2 \\
\hline >50 Tahun & 2 & $\mathbf{1 0 0}$ \\
\hline $\mathbf{2}$ & Total & $\mathbf{8 1}$ & \\
\hline & Diagnosis & & 20 \\
\hline & Normozoospermia & 14 \\
\hline Asthenoteratozoospermia & 16 & 47 \\
\hline & Oligoasthenoteratozoospermia & 1 \\
\hline & Oligozoospermia & 11 & 1 \\
\hline Oligoteratozoospermia & 38 & 17 \\
\hline Teratozoospermia & 1 & $\mathbf{1 0 0}$ \\
\hline
\end{tabular}

\section{Hasil Analisis Univariat}

Gambaran Jumlah Leukosit dan Motilitas Progresif Spermatozoa pada Responden Penelitian di SamMarie Family Healthcare Jakarta

Hasil analisis univariat penelitian di SamMarie Family Healthcare Jakarta tahun 2019 dapat dilihat pada Tabel 2. Data menunjukkan bahwa nilai tengah jumlah leukosit pasien sebanyak 2/LPB dan masih tergolong normal menurut hasil analisis semen lab SamMarie $(\leq 3 / \mathrm{LPB})$, begitu pula dengan persentase motilitas progresif sebesar $64 \%$ yang tergolong normal menurut WHO ( $\geq 32 \%)$.

Tabel 2. Distribusi Responden Menurut Jumlah Leukosit dan Motilitas Progresif Spermatozoa

\begin{tabular}{ccc}
\hline No & Karakteristik & Median \\
\hline 1 & Jumlah Leukosit (/LPB) & 2 \\
\hline 2 & Motilitas progresif $(\%)$ & 64 \\
\hline
\end{tabular}

\section{Pembahasan}

Distribusi sampel menurut usia menunjukkan bahwa pria yang paling banyak memeriksakan spermanya berada di rentang usia 30-39 tahun, yaitu sebanyak 46 orang (57\%). Beberapa peneliti lain juga mendapatkan distribusi yang sama, yaitu $56,1 \%$ pada penelitian Fajar T. Widodo (2009) dan 41,4\% pada penelitian Cokorda Bagus (2013) Hal tersebut mungkin terjadi karena rentang usia tersebut merupakan masa reproduktif, dimana pasangan yang sudah menikah akan mengharapkan terjadinya kehamilan. 
Mayoritas pasien yang memeriksakan spermanya memiliki diagnosis oligoasthenoteratozoospermia (47\%), dimana terjadi kekurangan atau ketidak sempurnaan pada jumlah, morfologi, dan motilitas spermatozoa. Hasil yang sama didapatkan oleh Cokorda Bagus pada penelitiannya di tahun 2013, dimana diagnosis pasien terbanyak adalah OAT (49.8\%). Hal ini menunjukkan bahwa masing-masing aspek parameter kualitas sperma akan memengaruhi parameter yang lain. Ketiga abnormalitas tersebut sering terjadi bersamaan dan merupakan penyebab tersering infertilitas pria (Jungwirth et al., 2010; Zhu et al., 2015). Pada proses spermatogenesis yang tidak optimal, spermatozoa yang dihasilkan akan memiliki morfologi yang kurang sempurna, morfologi atau bentuk spermatozoa yang tidak sempurna tentu akan mengganggu motilitasnya menuju ovum. Oleh karena itu seringkali gangguan motilitas spermatozoa menjadi penyebab infertilitas pria walaupun jumlah spermatozoa dalam batas cukup. Namun pada pasien dengan OAT mungkin terjadi gangguan pada proses spermatogenesis, baik pre-testikular maupun testikular, yang dapat memengaruhi seluruh proses kelanjutannya dan produk yang dihasilkan, sehingga terjadi infertilitas akibat jumlah,morfologi dan motilitas spermatozoa tidak optimal (Ganong, 2001; Tanagho, 2008; Widodo, 2009).

Salah satu penyebab gangguan pada spermatozoa adalah proses inflamasi pada saluran reproduksi pria yang dapat menyebabkan peningkatan aliran darah menuju organ target, peningkatan permeabilitas kapiler, dan peningkatan migrasi leukosit ke jaringan. Leukosit kemudian menghasilkan produk-produk inflamasi dan berkontak dengan spermatozoa di lumen epididimis sehingga mengganggu proses maturasi yang dapat berdampak pada motilitas, meningkatkan persentase spermatozoa statis di epididimis, dan menyebabkan infertilitas posttestikular. Semen dengan jumlah leukosit melebihi batas normal inilah yang disebut leukositospermia yaitu $\geq 1 \times 10^{6} / \mathrm{mL}$ menurut $\mathrm{WHO}$, atau $\geq 3 / \mathrm{LPB}$ menurut hasil pemeriksaan lab SamMarie Family Healhcare. Pada penelitian ini, rata-rata pasien memiliki jumlah leukosit yang normal (2/LPB), begitu pula pada bebeapa peneliti lain yang hanya menemukan sedikit sampel penderita leukositospermia (Widodo, 2009; Gregory et al., 2014; Azenabor et al., 2015).

Nilai tengah persentase motilitas spermatozoa pasien pada penelitian ini menunjukkan angka yang normal yaitu 64\%, begitu pula pada penelitian Fajar T. Widodo (34\%). Hal ini berbeda dari penelitian Zelshie Ansalsi pada tahun 2017 yang menemukan banyak pasien dengan asthenozoospermia.

\section{Hasil Analisis Bivariat}

Hubungan Antara Jumlah Leukosit dengan Motilitas Spermatozoa Pada Analisis Semen Pria di SamMarie Family Healthcare Jakarta

Hubungan antara jumlah leukosit dengan motilitas spermatozoa pada analisis semen pria di SamMarie Family Healthcare Jakarta dapat dilihat pada Tabel 3.

Tabel 3. Hubungan Antara Jumlah Leukosit dengan Motilitas Spermatozoa

Pada Analisis Semen Pria di SamMarie Family Healthcare Jakarta

\begin{tabular}{lcc}
\hline \multirow{2}{*}{ Variabel Dependen } & \multicolumn{2}{c}{ Variabel Independen } \\
\cline { 2 - 3 } & \multicolumn{2}{c}{ Motilitas Progresif } \\
\cline { 2 - 3 } & Koefisien Korelasi $(\boldsymbol{r})$ & P-Value \\
\hline Jumlah Leukosit & -0.328 & 0.007 \\
\hline
\end{tabular}

Tabel 3 menunjukkan bahwa $P$-value yang didapatkan dari uji Spearman lebih rendah dari 0,05 ( $P$-value: 0.007$)$ sehingga dapat disimpulkan terdapat hubungan yang bermakna antara leukosit dengan motilitas spermatozoa. Didapatkan korelasi $(r=-0.328)$ dengan arah hubungan terbalik 
(korelasi negatif), yaitu semakin tinggi jumlah leukosit dalam semen, persentase spermatozoa yang motil semakin rendah, dengan kekuatan korelasi sangat lemah (Sastroasmoro, 2014)

\section{Pembahasan}

Mekanisme lebih jelas mengenai bagaimana kontak leukosit dengan spermatozoa hingga dapat menimbulkan kerusakan masih belum jelas. Beberapa produk inflamasi memang memiliki perannya masing-masing dalam kerusakan spermatozoa, beberapa diantaranya yaitu: (1) Neutrofil, mendestruksi jaringan lokal; (2) Monosit, menghasilkan TNF $\alpha$ yang berperan dalam induksi apoptosis; (3) Interleukin (IL), menginduksi apoptosis; dan (4) Reactive Oxygen Species (ROS), menghasilkan molekul mutagenik dan genotoksik yaitu malondialdehyde (MDA) dan 4hydroxy-nonenal (4-HNE) yang mengakibatkan kerusakan DNA sperma dan mitokondria, sehingga terjadi penurunan ketersediaan ATP dan energi yang dapat memperlambat motilitas spermatozoa (Gregory et al., 2014; Azenabor et al., 2015; Wagner et al., 2018)

Terdapat beberapa pendapat dari penelitian-penelitian yang sudah pernah dilakukan. Beberapa peneliti menyatakan, bahwa jumlah leukosit memengaruhi kualitas spermatozoa. Namun, peneliti lain yang menentang hipotesis ini menyebutkan bahwa yang memengaruhi kualitas spermatozoa adalah ROS dan produk-produk inflamasi lainnya, bukan jumlah leukosit. Selain itu, faktor-faktor lain seperti usia, berat badan, pekerjaan, dan gaya hidup serta konsumsi rokok dan alkohol dikabarkan juga dapat memengaruhi kualitas sperma. Sedangkan pada penelitian ini didapatkan adanya hubungan bermakna antara jumlah leukosit dengan motilitas sperma, membuktikan $\mathrm{H} 1$ yang telah ditetapkan oleh peneliti adalah benar. Korelasi yang terjadi merupakan korelasi negatif dengan kekuatan korelasi sangat lemah $(r=-0.328)$, hal ini diakibatkan karena bukan hanya leukosit saja yang dapat memengaruhi motilitas sperma, tapi juga faktor-faktor lain yang sudah disebutkan sebelumnya (Tremellen et al., 2010; Gregory et al., 2014; Zhu et al., 2015; Azenabor et al., 2015; Ansalsi, 2017; Wagner et al., 2018).

\section{KESIMPULAN}

Berdasarkan hasil dan pembahasan yang sudah dipaparkan, dapat disimpulkan bahwa pasien terbanyak berada pada rentang usia 30-39 tahun sebanyak 46 orang (57\%), diagnosis pasien terbanyak yaitu oligoasthenoteratozoospermia (OAT) sebanyak 38 orang (47\%), nilai tengah jumlah leukosit semen masih tergolong normal yaitu sebanyak 2/LPB, begitu pula nilai tengah persentase motilitas spermatozoa yaitu sebesar 64\%. Dari hasil uji korelasi didapatkan hubungan negatif yang bermakna/signifikan dengan kekuatan korelasi sangat lemah antara jumlah leukosit dengan motilitas spermatozoa ( $p=0.007, r=-0.328)$ pada analisis semen pria di SamMarie Family Healthcare.

\section{Ucapan Terima Kasih}

Penulis mengucapkan terima kasih kepada SamMarie Family Healthcare Jakarta atas kesediaannya menjadi tempat penelitian dan terima kasih kepada dr. Tuty Rizkianti, Sp. PK dan ibu Cut Fauziah, M. Biomed atas saran, bimbingan, dan bantuannya.

\section{REFERENSI}

Agustinus. (2019). Infertilitas Laki-laki. Kuliah Blok Sistem Ginjal dan Saluran Kemih Universitas Muhammadiyah Surabaya 
Al-Haija RWMA. (2011). Main Causes of Infertility Among Men Treated at Razan Centers in West Bank: Retrospective Study. An-Najah National University. Thesis.

Ansalsi, Z. (2017). Hubungan Antara Motilitas Sperma dengan Jumlah Leukosit Cairan Semen Laki-Laki di RSU Citra BMC Padang (Tinjauan Rekam Medis). Skripsi. Fakultas Kedokteran Universitas Andalas.

Azenabor, A, Ekun AO, dan Akinloye O. (2014). Impact of Inflammation on Male Reproductive Tract. J Reprod Infertil.

Carrel, DT. (2013). Paternal Influences on Human Reproductive Success. New York: Cambridge University Press.

Dorland, WAN. (2002). Kamus Kedokteran Dorland. Terjemahan Huriawati Hartanto. Edisi pertama. Jakarta : EGC.

Ganong, WF. (2001). Buku Ajar Fisiologi Kedokteran. Jakarta: EGC.

Gregory, M and Cyr DG. (2014). The Blood-Epididymis Barrier and Inflammation. Landes Bioscienc.

Hardijanto, SS. (2010). Buku Ajar Inseminasi Buatan. Surabaya: Universitas Airlangga.

Henkel, RR. (2011). Leukocytes and Oxidative Stress: Dilemma for Sperm Function and Male Fertility. Asian Journal of Andrology.

Jungwirth, A, Giwercman A, Tournaye H, Diemer T, Kopa Z, Dohle G, Krausz C. (2012). Guidelines on Male Infertility. European Association of Urology.

Lackner, JE, Agarwal A, Mahfouz R, du Plessis SS, Schatzl G. (2010).The association between leukocytes and sperm quality is concentration dependent. Reproductive Biology and Endocrinology.

Parrott, FR. (2014). 'At the hospital I learnt the truth': Diagnosing Male Infertility in Rural Malawi. Anthropology \& Medicine.

Pereira, R, Rosalia S, Alberto B, Mario S. (2017). Major Regulatory Mechanisms Involved in Sperm Motility. Asian Journal of Andrology.

Piomboni, P. (2012). The Role of Mitochondria in Energy Production for Human Sperm Motility. European Academy of Andrology.

Putra, CBN dan IBG Fajar Manuaba. (2013). Gambaran Analisa Sperma di Klinik Bayi Tabung Rumah Sakit Umum Pusat Sanglah Tahun 2013. Denpasar: Fakultas Kedokteran Univesitas Udayana.

Sandoval, JS, Douglas R, Suheil M. (2013). Leukocytospermia: Overview of Diagnosis, Implications, and Management of a Controversial Finding. Middle East Fertility Society Journal.

Satroasmoro, S dan Sofyan I. (2014). Dasar-dasar Metodologi Penelitian Klinis. Jakarta: Sagung Seto.

Sheikh, N, Iraj A, Marzieh F, Rezvan N, Jafar H. (2008). Correlation Between Sperm Parameters and Sperm DNA Fragmentation in Fertile and Infertile Men. Iranian Journal of Reproductive Medicine.

Shi TY. (2009). ROS Originated from Leukocytes: Impact on Movement, Viability and Morphology of Cultivated Human Sperm. Asian Journal of Andrology.

Singh A, Agarwal A.(2011). The Role of Sperm Chromatin Integrity and DNA Damage on Male Infertility. The Open Reproductive Science Journal. 
Tandara, M, Bajic A, Tandara L, Sunj M, Jurisic Z, Jukic M. (2013). Correlation Between Proportions of Sperm with DNA Fragmentation Assessed by Halosperm Test and Values of Standard Quality Parameters of Semen and Possible Impact on Embryo Quality. Zdrav Vestn.

Tanagho, EA. (2008). Smith's General Urology. 17th edition. McGraw-Hill.

Tremellen, K dan Tunc O. (2009). Macrophage Activity in Semen is Significantly Correlated With Sperm Quality in Infertile Men. International Journal of Andrology. Australia.

Vieira, M. (2013). New WHO Reference Values for Semen Analysis: Where Do We Stand?. Sao Paulo.

Vignera, SL. (2012). Effects of The Exposure to Mobile Phones on Male reproduction: A Review of the Literature. Section of Endocrinology, Andrology, and Internal Medicine. Department of Internal Medicine and Systemic Diseases. Catania University.

Wagner, H, Cheng JW, Ko EY. (2017). Role of Reactive Oxygen Species in Male Infertility: An updated review of literature. Arab Journal of Urology.

Widodo, FT. (2009). Hubungan Antara Jumlah Leukosit dengan Motilitas Sperma Pada Hasil Analisa Sperma Pasien Infertilitas di RSUP dr. Kariadi Semarang. Laporan Akhir Penelitian. Fakultas Kedokteran Universitas Diponegoro.

World Health Organization. (2010). Laboratory Manual for Examinaton and Processing of Human Semen. 5th ed.

Zhu J, Blagica A, Dance V, Andrijana SA, Kristina K. (2015). Case Report : Oligoasthenoteratozoospermia, treatment with acupuncture. Macedonia: University Goce Delcev-Stip. 